\title{
Working in Developing Countries ${ }^{1}$
}

\author{
by \\ J. J. E. Dosne ${ }^{2}$
}

In his New Year's message, our Prime Minister mentioned that "Canadians should mind the cries of anguish from underdeveloped nations and open their eyes to their own good fortune". There is considerable importance nowadays of North to South aid or Western aid to the Third World countries, essential for world stability and the thinking that today's aid recipient will become tomorrow's trading partners.

Let us look at our own field of forestry. There is a very small proportion of Canadian graduate foresters working in developing countries. Because of our own experience, we are known to have a practical understanding of the problems of development, as compared to Europeans; also, because of the advanced state of forestry in Canada and our bilingualism, we have much to offer developing countries in terms of inspiration, understanding, communication and technical assistance. These, in turn, have important implications for the effectiveness of our international relations, for we now live in a world community, where one can no longer ignore the existence of others.

Most Canadians have considerable lack of knowledge about aid programs. All they hear is the bad publicity journalists have given CIDA, they never hear of the many successful projects. The country has never come close to the UN's foreign aid goal of 0.7 percent of gross national product. It is now at 0.5 percent of $\$ 1.2$ billion as reported by CIDA. Of this amount, approximately $60 \%$ (represented in salaries and equipment) stays in Canada.

For consultants alone, the Financial Times recently reported that last year, overseas contracts earned Canadian consultants more than $\$ 300$. million - an amount that has doubled compared to 5 years ago.

Developing Countries are constantly and increasingly in need of professional foresters. The technological level of our profession, as well as the forest economic development of the developing country are the important factors in determining the kinds and numbers of foresters the country needs.

Tropical countries have $1 / 2$ of the world's forest land and also the world's greatest underexploited land resource. They also have more than $1 / 3$ of the world's population and $42 \%$ of the earth land area.

Tropical Forests are far more diverse and complex than temperate forest ecosystems. Nearly all tropical forests are found in 3 broad regions, i.e., South and Central American $42 \%$, Africa $37 \%$, Asia $21 \%$. For forestry development in these tropical countries, consideration must be given to the equally diverse social, cultural, economic and political conditions which exist.

These countries have a multitude of species and woods of superb qualities. With rates up to $400 \mathrm{cu} . \mathrm{ft}$./acre/year, many precious woods and various secondary species to develop, these nations obviously need foresters, forest industries and reforestation activities. There is a vast need particularly for improved housing and productive jobs. For these reasons, extending our interest to these countries can be of great value.

Canadian forestry should not feel threatened or consider that the development of forestry in 3rd World countries could harm their own forestry potential. On the contrary.

\footnotetext{
${ }^{1}$ Paper presented at an FAO committee meeting in Ecuador, SA.

${ }^{2}$ Consultant in tropical forestry, Pointe Claire, Que.
}

Canadian firms in forest or pulp and paper industry projects stand to benefit from expanding their overseas operations.

The developments will complement the Canadian industry and the world demand for wood. With increased population as well as an improved education system, this demand for wood products should mainly be for the use of developing countries themselves.

If we base these future world needs on FAO's recent forestry statistics, Canada's overall forest product industries can theoretically double or triple in the future and the tropical forests supplying some of the world's market requirements should not affect Canada.

Technical Assistance is the term used by all international organizations. Developing nations badly need modern technology. They need to learn how we approach problems and find solutions. One needs to know how local people think - and to appraise their willingness to discard the traditional. The major types of technical assistance are in government services, industrial forestry and in teaching and research

The following are some of the urgent needs and interests of the various continents in the forestry sector:

Middle East:
Far East:
Central America:
West Indies:
South America:
French Africa:

Reforestation and Forest Industries Forestry Education

Agro-Forestry (silvi-pastoral)

Forest Development

Forest Operations

Forestry Education and Forest Operations

Sahel Countries: Projects to combat the desertification English Africa: Agro-Forestry (agro-silvi) and Wildlife Management

All of the developing countries now in forestry development are interested in reforestation/afforestation, in environmental studies and in the recent developments of agroforestry.

Agro forestry is rapidly gaining popularity as a science of various disciplinary subjects. As it is for the benefit of rural populations, it denotes all activities in land utilization where the production of food goes hand in hand with the production of wood. Both the short-term and long-term rotations are observed. The more technical term of agro-silvi-pastoral is land management for the concurrent production of food crops and/or livestock with trees.

Almost all of the projects are of technical assistance to the government services for rural-urban development and for the benefit of the poor. However, the attitude that forests belong to the government and of little concern to the people is a major drawback in forest development.

The Advantages and Disadvantages of working in developing countries are numerous. The following are only five of the advantages and disadvantages:

\section{Advantages}

- Professional challenge

- Excellent salary

- Attraction and fascination of a foreign country

- International experience

\section{Disadvantages}

- Away-from-home

- Children's education

- Health risk and hazards

- Poor living facilities 
- Sense of contributing to the betterment of less privileged people

- Away from Canadian living standards

If you are of the type with sand in your shoes - the love of travel and the interest in different people and different countries are also advantages, but not to be considered as the only advantage.

In most cases, two years should be enough to get a project on the way. Away-from-home and family is probably the biggest disadvantage in 3-6 months projects, although shortterm projects are now more common. In most countries, the children's education can be considered as an advantage when they are starting school but a disadvantage when they need higher education. The travelling and the learning of cultures and languages is an education in itself. The comparison with your country is always interesting. One may apply the dicton here to "see the world and you return more Canadian than ever."

Isolation and a lot of travelling is part of many Canadians forester's life, by the very nature of his work. An international forester's life is often the same, it also means in some cases putting up with the minimum of basic requirements when he is in the forest, and, sometimes one must do the best with the least.

How to obtain a foreign assignment: Many young foresters have asked how to obtain a foreign assignment.

The following five points should be considered:

1) The study of the history and culture as well as the forest possibilities of the developing nations.

2) The study of languages. An international expert is usually linguistically inclined. English, French and Spanish are the official languages of the United Nations. A working knowledge of the language of the country of assignment is most important.

3) The completion of a university course is essential. The more degrees or the more advanced education the better the chance of recognition and good remuneration by international organizations.

The selection of a significant topic in tropical forestry for a university thesis is a good start. If this requires collecting material in developing countries, there are now fellowships available to finance such a study. Many professors go on short-term missions overseas and usually know of opportunities for students.

4) Any travel of experience abroad is an asset. Sometimes Canadian industries or major forest industries or corporations have operations abroad.

5) Good health, and a family which will also appreciate the experience is a basic requirement.

The following ten organizations listed in alphabetical order are some of the international organizations presently interested in Canadian Foresters:

CIDA - Canadian International Development Agency (also IDRC)

FAO - Food and Agriculture Organization of United Nations

IBRD - (World Bank), International Bank for reconstruction and development.

IDB - Inter-American Development Bank.

IFAD - International Fund for Agricultural Development (also ICRAF)

OAS - Organization of American States

(Central and South America).

OPEC - Organization of Petroleum Exporting Countries

UNDP - United Nations Development Programme

UNSO - United Nations Sodano-Saheliön Office

USIAID - US Agency for International Development
The International Forester was described by FAO a few years ago as "a mature forester, expert in his own land, who because of this, is sought out for service abroad". The purpose of the world forester, as he is also called, is not to take over or to replace work of the local forester or representative of the developing country. Rather he is attempting to build a system to install the know-how to do the work, so that the project is ultimately turned over to the local people to manage. Inconveniences, frustrations and political dealings are to be encountered and this is sometimes not easy to take.

The liaison of the international expert and the country is usually through a counterpart. Communication between the foreign expert and his local counterpart is sometimes difficult even when they speak the same language. For this reason, a reasonable amount of time spent in understanding the background and the thinking of the people in the foreign land is of great help, and also in developing friendships between countries. The richest satisfaction from service to a developing country is to feel that you are part of its struggle and that personally you have made a contribution.

The forester must by his actions demonstrate that he is interested in helping his host country to achieve its ambitions. $\mathrm{He}$ needs to encourage them to participate in various lines of action, to weigh the possibilities and together to decide on the most likely approach to be accepted and to be successful. He has the enthusiasm and he wants to see a success of his project developed - but adapted to the conditions of the country, which can sometimes strain your best intentions.

Foresters are by nature idealists as well as naturalists. Otherwise they would have chosen another means of livelihood. They are also practical and broad-minded. A failure of many experts abroad, particularly those on shortterm assignments, is to think of their project as involving solely their own field of competence. The forestry approach must be supported by other branches of the country's economy and development.

Instead of few experts, hundreds of professionals are now required. Experts today also need to be acquainted with the latest and most sophisticated technologies. We should have more of an international flavour in our universities - such as tropical forestry courses in some of our faculties so that we can have a greater percentage of foresters to deal with international forestry.

Forestry on our international level has its challenge and its rewards. One of the greatest assets is the sense it gives of contributing in a very meaningful and practical way to the betterment of people in poor countries. They have the resources but they are lacking in the technology. That is the meaningful part. The practical part is that the tropical forests have such short rotations that we can not afford to overlook its possibilities for our own sake.

The Canadian forester has the required know-how and has the advantage of having one of the most accepted passport. Canadians are known to enjoy the professional challenge and to concentrate on their project - they are usually not interested in the politics of the country - a distinctive advantage in many cases.

All Canadian foresters who have worked overseas will agree that there is a great deal of personal satisfaction involved in knowing that in some way, they have contributed to the advancement of developing countries. 